\title{
Theoretical foundations of the Bratislava School of Business Ethics
}

\author{
Anna Remišová \& Anna Lašáková
}

\begin{abstract}
The aim of this article is to explain the key theoretical foundations of business ethics as a social scientific and academic discipline that was established and further developed at the Faculty of Management at Comenius University in Bratislava. The authors of this article refer to this school of thought as the "Bratislava School of Business Ethics" with the intention of pointing out its relative autonomy in research and higher education in the Slovak academic environment.
\end{abstract}

Keywords: integrative business ethics, Bratislava School of Business Ethics, ethical rationality, economical rationality, ethical behavior, unethical conduct, managerial ethics

\section{Introduction}

The development of business ethics over a quarter of a century at economics-oriented universities has been symbolically crowned by the acknowledgement to integrate ethical education into a system of long-term and systematic university education of prospective managerial professionals. In 2017, the Faculty of Management at Comenius University in Bratislava (FMCU) started to implement an accredited study program of Management within the field of study of Management, which includes teaching a course of business ethics as a compulsory subject. For the first time in Slovakia, the academic discipline of business ethics became a part of the obligatory intellectual "equipment" of a professional manager. The transition from an optional course to an obligatory subject is of great importance for the development of business ethics in theory and practice.

This occasion has inspired our effort to clarify the theoretical postulates of the business ethics concept, which originated at FMCU and which forms the basis of pedagogical education and scientific research at this faculty. The authors of this article consider themselves as representatives of this coherent concept, which has already been developed for the three decades. They suggest titling this stream of thought as the Bratislava School of Business Ethics (BSBE). In this article, they focus on clarifying the basic postulates of ethical and entrepreneurial-ethical theories, on which the BSBE is based.

\section{Basic postulates of BSBE}

The formation of a uniform and systematic understanding of business ethics as an academic discipline at BSBE was initially outlined in the works of Anna Remišová, first at the University of Economics in Bratislava (during the 1990s) and consecutively (since 2000) at Comenius University in Bratislava. The key standpoints of the Swiss professor Peter Ulrich published in the seminal works Transformation der ökonomischen Vernunft (1993) and Integrative Wirtschaftsethik (1997) had a fundamental influence on her thinking and approach to business ethics.

The BSBE is partially rooted in Ulrich's theoretical and methodological standpoints and is based on five pillars. These basic postulates are as follows:

1. Business ethics as social science represents an integration of ethical and economic rationalities.

2. The economic sphere forms one of the spheres of social life and its basic mission is to procure basic life needs, i.e. service to life. 
3. The key ethical-economic issue in business ethics is the relationship between ethics and profit.

4. Managerial ethics as the normative regulation of professional activities of managers is an important ingredient of business ethics. The ethical conduct of managers (ethical leadership) is central to the successful application of business ethics principles into organizational practice.

5. The BSBE assumes that the nature of organizational practice necessitates for a pluralistic and synthesizing approach to business ethics, integrating several theoretical approaches to ethics.

These five postulates accompany the development of the BSBE from its beginnings to the present and appear in the academic didactic preparation of the educational process. They serve as the starting point for scientific projects and related research in the field of business ethics at the FMCU.

\section{Business ethics as a social science represents the integration of ethical and economic rationality}

Business ethics as an academic discipline was formed in the 1970s and its development is accompanied by a number of attempts to define it. The interdisciplinary nature of business ethics is not questioned by researchers; what causes theoretical and methodological problems is related to the understanding of the potency of application of its normativity. Business ethics is about to uncover the mystery of interconnecting two methods of thinking about two legitimate ways of human cooperation. Its primary task is to explore the relationship between the theoretical disciplines of ethics and economic science and the real relationship of morality and economics in social practice. The mission of business ethics as a social science is to provide insights that not only explain the aforementioned relationships but also to guide on their application and use in the real live of individual persons, groups or society as a whole. Business ethics is therefore normative in nature and its acceptance should become a regulator of economically active entities.

According to the BSBE, the rise and subsequent expansion of business ethics represents the beginning of a new socio-scientific paradigm that disrupts the two hundred year paradigm of the separation of economic thinking and economic systems from values. The thought tradition of understanding the perfect functioning of the economic order solely on the basis of economic calculations and characteristics has proved to be illusory, theoretically and practically inoperative, because it failed to explain and subsequently solve real socioeconomic and environmental problems.

The constitutive definition of business ethics at FMCU is as follows: Business ethics is a normative social scientific discipline that examines the integration of ethical and economic thinking and the integration of ethics and economics in all areas and at all levels of the economic system (Remišová, 2015).

This definition is based on the justification of the elimination of the dichotomy of economic and ethical rationality and on the demand for the introduction of ethical reflection into economic life in all its breadth and diversity. The essence of such an understanding of business ethics lies in bridging economic and ethical rationality to a single cognitive entity. The first author to create a concept of business science based on the integration of economic and ethical thinking and the integration of ethics and economics was Peter Ulrich (Ulrich, 1993; Ulrich, 1995; Ulrich, 1997).

Economic rationality is a way of rational reasoning applied by economically active entities. It is a way of thinking about how to achieve an economic goal in the state of permanent limitation of resources, e.g. human, natural, monetary, or informational resources. Economic rationality, understood as technical rationality, in itself, is not ethically problematic. What is 
ethically problematic, however, is its dogmatic enforcement in a modern market economy that brings not only satisfaction of the economic needs of the planet's population but also a huge number of social and ecological problems, including the threat to human existence. The social and ecological reality around the globe, forming since the second half of the $20^{\text {th }}$ century, has its roots in an unregulated economic rationality that prefers individual particular interests of the members of the society and not the interests of the society as a whole.

Ethical rationality is a way of thinking based on the search for universal rules of human coexistence and cooperation of people and with the natural environment. Morality is a distinguishing feature of human existence, it is the basis and at the same time the way of cooperation of human beings. Ethical rationality reflects the development of human thinking in the field of desirable human behavior. The current minimal ethical bases in interpersonal cooperation and coexistence require respect for every human being as a respectable creature whose life and activity on any part of the planet and in any human sphere are based on respect for human rights. The form of integration of this ethical rationality with economic thinking should acquire the character of "socio-economic rationality", that is the rationality which has "an ethical reason already in itself" (Ulrich, 1997, p. 96).

\section{Economy is "only" one of the spheres of society}

Economic action is an integral part of human life. The history of mankind shows that man has entered labor division at a certain stage, and has since ensured the satisfaction of needs through cooperation with others who produce. Pre-modern economic theories from Aristotle to Smith refer to normatively closed types of societies where economic life does not protrude beyond other social spheres but is one of them, and in the same way to them, it is embodied in the social and cultural ties of wider social life. The social anchor of the economy was of a dual nature; on the one hand. economic life was based on moral norms that were binding for the community, and it was penetrated by them, and "the economic aims and motives were thus comprehensively subordinated to the social ideas of good life and fair coexistence" (Ulrich, 1997, p. 132). On the other hand, the organization of the economy was "complexly connected to traditional institutions of everyday life" such as family, community, church (Ulrich, 1997, p. 133).

The modern market economy no longer derives from traditional moral standards, either bypassing them or making use of them in favor of achieving economically rationally set individual or particular goals. And as far as economic organizations are concerned, they are not organically associated with traditional institutions such as family, community, or church, but the market economy begins to control and to colonize them. Whereas in pre-modern societies various social spheres of life stood "side by side", modern economy dominates these institutions - it has infused them as a way of managing economic bonds, economic relations, economic values, economically rational thinking. Arts, sports, health, education derive no longer from their own mission in the society, but they take on the function of economic units, and manage themselves based on economic calculus, economic values and economic relations. The world of life - the Lebenswelt, as the German philosopher Jürgen Habermas titled it, is colonized by the economic thinking.

Our present is associated with the existence of a capitalist economic system in its globalized form, which from an economic point of view represents almost perfect pure economic rationality - the global player works with limited global resources in such a way that their use for the realization of business goals would be the most economically advantageous. Economic, and not the ethical, social or environmental value, remains the priority value of an economically active entity.

The BSBE promotes a critical insight into the ultimate role of the market in the modern economy. Market economy perceives market cooperation as "the principle of purely 
economic creation of the social world", which changes the people who participate in the economic activity into "Homo oeconomicus", where the key market position takes up the character of an ideology of the total market community (Ulrich, 1993, pp. 127-129).

The market is one of the basic structural elements of modern capitalist economy. Market cooperation is seen in the BSBE as one of many other ways of coordinating human cooperation that has proved to be functioning and effective. However, its utter dominance and the attribution of quality of something objectively and totally independent of society are misleading. The market is a social institution that originated within the society, and as such it is not a natural or supernatural phenomenon. As a social phenomenon, it has its characteristics, which also include its social cultural anchorage. In human society there is a more broadly conceived social cooperation than the market one - it is the morality-based cooperation that works on the basis of recognition of the existence and interests of another person.

\section{Relationship between morality and profit}

The basic regulatory idea for the economic thinking of an economic actor in a modern market economy is profit. Business ethics as an integrative social scientific discipline is based on a serious critique of economics in its understanding of profit and of the key economic "costrevenue" linkage. According to the BSBE, this type of reasoning fosters the idea that it is an independent economic criterion that provides the economy with precision and objectivity. Modern economic theorists are dominantly convinced that if the profitability and return on investment can be mathematically calculated, the economic world operates on a scientific basis, is autonomous, and no regulatory interventions are needed.

The concepts of profit and maximization of profit are closely related to the "costsrevenues" logic. Profit is the basic structural element of a market economy, and it seems that in the current economic world - both theoretically and practically - has the status of an untouchable deity. In the understanding of business ethics according to the BSBE, profit is perceived as an economic category that is neither ethical nor unethical. Profit is one of many economic tools to evaluate the entity's economic activity. Profit as an economic criterion for success in the economic world is linked only to the economic interests of one (individual or collective) economically active actor, and generally refers only to profit expressed in a financial form.

The BSBE accepts the place of profit in the market economy. However, ethical reflection of profit is essential. Profit can be evaluated as ethical or unethical. Profit is unethical if it is created in an unethical way or it is used in an unethical way. An economic entity that generates profits in an unethical way is unethical. Furthermore, an economic entity is also unethical should it redistribute its profit in an unfair manner (e.g. unfair employee remuneration, toxic investments). An economically active entity can generate profit in the long run and be ethical. Its true attitude to ethics will be revealed in a situation where profits come into conflict with ethics. In the BSBE the concept of business ethics is based on the idea that in the case of an irreconcilable conflict between ethics and profit, ethics is preferred over profit, i.e. human, humane and accountable conduct is given priority over economically successful conduct (a conduct that is fruitful usually only for an individual or a limited group of people). In addition, the BSBE regards profit in a wider sense, not only as an economic constant, but as a social and environmental issue; for instance, employee development, provision of social opportunities, or environmental protection may be regarded as diverse facets of profit.

\section{Ethical theoretical framework of BSBE}

Business ethics is applied ethics, meaning that it is a social science that applies ethical knowledge to the field of economics and human action in the economic sphere. At this point, 
the BSBE differs from the understanding of business ethics as seen by Peter Ulrich, who opposes the idea of business ethics as applied ethics, fearing that in this form it would be reduced only to a social technique of solving economic problems, thereby losing its criticallyreflective and integrative character. He argues that economics itself, as the ideal theory of rational ethically active entities, is a normative theory that applies the benefit principle for the business environment, but it is absolutely insufficient for business ethics.

The primary ethical starting point of the BSBE is Kant's deontological ethics, his understanding of unselfish moral behavior, and the application of the categorical imperative in its three meanings. "The basic formulations of a categorical imperative can be translated into a simple sentence: [O]ne can only speak of morality if he can appreciate another person with the same degree of respect he attributes toward himself. Relation to oneself represents form of the other side the relationship to another person. Self-esteem does not work without respect to every other person" (Muránsky, 2008, p. 350). On this ideological basis, we have come to the abovementioned point of view: ethics is placed before profit, i.e. humanity is placed above the economic interest of an individual or a group. Kant's universalistic and humanistic ideas are reflected fully in the conception of business ethics as a social scientific discipline, which is part of a new socio-economic paradigm, where economics and ethics are integrated more as two modes of human coexistence based on cooperation. This understanding of business ethics differs from utilitarian ethics, which is considered to be the ideological justification of modern capitalist market economy and neoclassical economics.

The BSBE follows Remišová's understanding of applied ethics as a theoretical reflection of the morale of individual social spheres and activities, which contains not only an ethical expert analysis of phenomena and issues in a given social sphere, but also focuses on a critical analysis of itself. In doing so, business ethics is also an application of a complex general ethics to the whole range of theoretical and practical problems in the economic sphere, and it is also a theory of ethical application (Remišová, 1999, p. 233).

In the analysis of economic behavior from an ethical standpoint and in the search for ways of integrating ethical and economic rationality, various concepts of business ethics are based on different ethical theories and concepts, examining morality, its origins, structure, basis, nature of ethical knowledge or methods of investigation and criteria of the truthfulness of ethical knowledge, which form the social science of ethics in its complexity and systemic nature. In essence, the BSBE emphasizes that there is not just one ethics, but there is a social scientific discipline formed by various ethical theories and more or less complex concepts that examine some of the ethical issues, deepening what has been already explored, and discovering novelties in moral human action and reasoning. No single ethical theory should entitle itself to an absolute solution of moral and ethical problems because it represents only one part of the enormous effort of the human intellect to theoretically and critically assist mankind and humanity as a whole to achieve a new quality of human coexistence and cooperation based on nonviolent communication and humanity. In addition, new scientific knowledge from the field of natural, technical and social sciences is shifting the borders of knowledge on the quality of human coexistence and human behavior that ethical theories cannot ignore.

In the process of critical moral and ethical reflection in the economic sphere, it is often insufficient to apply only one ethical concept to the area investigated. For instance, in modelling the construct of the ethical leader, we have drawn from the origins of these ethical theories: virtue ethics, deontological ethics, human rights ethics, ethics of responsibility and ethics of justice (Remišová \& Lašáková, 2013; Remišová et al., 2016). In our opinion, the leader we designate as ethical:

- has certain ethical virtues such as honesty, tolerance, fairness, decency, reliability, and personality integrity (virtue ethics), 
- bears responsibility to not to harm others; prioritizes ethical rationality over economic rationality in case the two cannot be reconciled in the decision-making process; keeps distance from unethical behavior of others jointly with clear communication of expectations related to ethical behavior of subordinates, verbalizes the importance of ethics in the workplace; distinguishes among subordinates based on their ethical conduct; and has self-reflection to be able to continually develop personally and professionally (deontological ethics),

- respects human rights, openly and clearly communicates with others and helps to develop their potential (human rights ethics),

- is able to consider the consequences of his/her own behavior and decisions and takes personal responsibility (ethics of responsibility),

- considers objectivity and justice important and keeps up these two ethical principles (ethics of justice).

Another example of the integration of diverse ethical knowledge and methods into the economic sphere is the BSBE itself that Remišová (1998), following Ulrich (1997), characterizes as rationalist, humane, and discourse-oriented. These three features present the application of different dimensions of ethical knowledge: the way of thinking, the basic ethical principle and the way of dealing with inconsistent standpoints.

The way of thinking: Business ethics is rationalistic. That is, it recognizes logical, reasoned and justified knowledge as the basis of human coexistence. Critical reflection of morality is based on evidence and argumentation as utilized in the scientific world, with the acceptance of the peculiarity of human coexistence and action as the subject matter of the study. Business ethics represents a critical reflection of the whole economic sphere and the activity of all economic subjects.

The basic ethical principle: Business ethics is based on the idea of humanity. That is, the acknowledgement of the dignity of a human being, as interpreted in the works of Immanuel Kant (Kant, 1999; Kant, 2004). Humanity means accepting another human being as a being who, like me, is a rational being and as such is worthy of respect, and not to use this autonomous being as a means to attain personal goals. The principle of humanity is a rational justification of the primary principle of morality - consideration of others in my own actions. The factum of reason and the factum of mutual recognition of others are the absolute primary principles of peaceful human coexistence.

The way of conflict resolution - discourse: Discursive ethics rationally justifies the solution of cohabitation with a focus on addressing potential or real conflict in human coexistence (Apel, 1992; Habermas, 1992). For business ethics, which is confronted with permanent tension between the interests of individuals and groups, this point is immensely important. It connects both rationalistic and humane principles. It requires human beings to resolve their conflicting coexistence in a nonviolent way - that is, by means of reciprocal recognition of the right of another party for respect, and taking into account the interests of those affected by a given decision.

\section{Ethical and unethical conduct of managers: Integration of ethical motives and ethical consequences}

Business ethics is normative in nature, and the specification of the initial ethical normative theory is crucial for the application of business ethics into practice, since the initial normative theory gives answers to the questions of "what the manager should do?", "how to decide ethically correctly?" "what his/her intention should be?" or "what behavior can be considered ethical?"

The peculiarity as well as the complexity of the application of ethical normative theories to the economic sphere and to the conduct of economically active entities, especially managers, 
stems from the fact that the traditional division of normative ethics into deontological and consequentialist ethics appears in this area to be too "narrow". By avoiding a detailed discussion on the division of normative ethics, it can be stated briefly that the main criterion for their division is the attitude towards the solution of the second fundamental question of ethics; what action is ethical? Thus, to specify to what primacy belongs in determining the ethical behavior of a moral agent: to the motive or to the consequence of agent's conduct. In accordance with deontological ethics, conduct is ethical only and under such condition when the motive is ethical, or when the sum of righteous, good, positive, etc., prevails over the wrong, non-positive, or poor. What consequences are considered to be ethically correct, positive or good is further discussed in particular in the context of consequentialist ethics (Gluchman, 2008; Gluchman, 2017).

In the BSBE debate over normative ethical foundation it has shown that in business ethics, which is based on the integration of ethical and economic reason, it is not possible to accept only one normative ethics. In accordance with BSBE, both deontological and consequentialist ethical theories are essential. An attempt to build a concept of business ethics as an integrative and normative science on only one of them proved to be unrealistic. Economic activities conducted through human decisions and actions cannot be considered ethically relevant, as long as they are evaluated only either from the stance of ethical motives or from the position of consequences. We consider the conduct of a manager as ethical if it is based on an ethical motive and at the same time its consequences do not harm others (Lašáková, Remišová \& Búciová, 2015).

Particularly crucial was the discussion on the ethical normative basis in defining a manager's unethical behavior. In the manager's activities, good motive alone does not guarantee that the consequences of the action will not harm anyone (in the broadest sense of the word). Therefore, it is vital that the manager in decision-making would be able to predict the influence of the decision on others. The manager's work epitomizes a continuous decision-making process that affects a large number of people and the natural environment within both the closer as well as more distant time horizons. Considering the consequences of actions, as well as the ethical reflection of the action itself, elements of the professional equipment of an ethical manager are essential. We define unethical managerial conduct as conduct that has an unethical motive and/or it harms others, be it individuals, organization and/or society as a whole (Lašáková \& Remišová, 2015).

We emphasize that ethical conduct is only such an action that has an ethical motive, that is, the motivation, impetus or intent of a person to act is ethical. Or, paraphrasing Kant, the subject's acts are morally selfless. In conceptualizing the manager's ethical behavior, the motive itself cannot be excluded from the evaluation of ethicality/unethicality, at least because the manager as a professional subject has to have personality integrity - if his/her motives are unethical, his/her colleagues will sooner or later reveal it and such a manager will be "ethically disqualified". In modern theories on ethical leadership, the unity of personality characteristics of the manager and the ability to lead others (subordinates) toward ethical conduct is clearly preferred (Trevino, Hartman \& Brown, 2000). At the same time, it should be noted that we do not understand the motivation of a person as something "flat" but as something multidimensional and developing in accordance with gaining new knowledge and experiences.

Today's economic knowledge is dominated by the concepts of corporate social responsibility and stakeholder theory, which point to the fact that, besides economically active business entities, there is a number of social groups that have their legitimate interests. The professionalism of the current manager lies, among other things, in identifying these groups, recognizing their legitimate (social, socio-cultural, economic and environmental) interests and the consequences that managerial decisions have on these groups. In accordance with 
professional ethics, the manager is required to take these interests into account and to reevaluate them from the point of view of ethics. In other words, ethical managerial decisionmaking includes ethical motivation to act as well as ethical reflection of the consequences of the actions, followed by acceptance of ethical responsibility for such conduct (Lašáková \& Remišová, 2017). In this respect, the manager's decisions are based on both deontological and consequentialist ethical knowledge.

Is our delineation of a manager's ethical behavior controversial from the point of view of ethical theories, or is the application of the motive and consequences of the manager's conduct a logical conclusion of our understanding of business ethics as an integrative science? At the given stage of development, it seems impossible to comprise ethically correct managerial decision-making only under one or another normative theory. Classification of theories is a necessary reasonable act, but the reality may be more complex than the division itself. The motive and the consequences of the action do not exist in the form of two isolated intellectual entities, but they are organically linked in managerial decision-making and subsequently in management. In this process, both the ethical self-reflection of the actions and the decision to accept responsibility for (un)ethical conduct play an important role.

The trend of integrating the deontological duty and the consequentialist considerations about the consequences of actions is also evident in the concept of professional managerial ethics. Accordingly, humanism and responsibility are the main principles of regulating managerial behavior (Ulrich, 1995; Remišová, 2011; McDonald, 2015; Dierksmeier, 2016).

We consider the issue of the criteria according to which the consequences of actions are evaluated from the point of view of ethics as a complex theoretical as well as practical and pedagogical-educational problem. The standards of ethical conduct, that is the criteria of correct and incorrect, moral and immoral, or put differently the criteria of morally correct and morally incorrect acts are extensively discussed (Gluchman, 2008; Gluchman, 2017). We believe that the consequences of any particular action from the point of view of ethics can be judged from different ethical positions - for example from the position of human rights ethics, ethics of justice, virtue ethics, ethics of duty, or discourse ethics, or from the position of values. Moreover, the evaluation of ethicality of actions as a process itself is carried out not only by the manager but also by other subjects. Their verdict depends on how a manager's actions affect the interests of the evaluators and what their ethical and intellectual abilities are. It is clear that the assessment of those people who were affected by a manager's conduct may be different from the assessments of the parties not directly affected.

\section{Conclusion}

We have drafted this article not as a deep theoretical dive into the issues of all areas which the representatives of the BSBE have been dealing with since its inception, but as a comprehensive overview of its basic theoretical positions with the focus on the ethical and entrepreneurial-ethical aspects. We have set out to clarify the essence of an integrated understanding of business ethics as an integration of ethical and economic rationality, its critical reflective character and humanistic orientation. The basic motivation to recapitulate the theoretical backgrounds of business ethics lies in a noticeable increase in the impact of business ethics as an academic discipline on the ethical reasoning and conduct of managers by means of an introduction to business ethics as a compulsory course at FMCU since 2017. In the past years only several dozen students (both Slovak and foreign) have graduated from business ethics; however, in the new intellectual space the numbers of students will be counted in hundreds - we expect about 500 graduates per year. The responsibility of BSBE lecturers and researchers for the formation of ethical thinking, ethical reflection and respect for professional managerial ethics has grown to an unprecedented extent. 


\section{Acknowledgement}

This work was supported by the Slovak Research and Development Agency under the contract No. APVV-16-0091.

Anna Remišová is a full professor at the Faculty of Management, Comenius University in Bratislava, Slovakia. She researches at the theoretical - as well as at empirical level - issues regarding business ethics, managerial ethics, corporate codes of ethics, forms of institutionalization of business ethics, and meta-ethics. She teaches Business Ethics, Business Ethics in HRM, Managerial Ethics, and Corporate Codes of Ethics.

Anna Lašáková is an associate professor at the Faculty of Management, Comenius University in Bratislava, Slovakia. As for research interests, she focuses on ethical and unethical leadership, modelling ethical employee conduct in organizations, and intercultural management. She teaches Organizational Behavior, Leadership, Business Ethics, Corporate Codes of Ethics, and Managerial Ethics.

\section{Corresponding author:}

Anna Remišová, Faculty of Management, Comenius University in Bratislava, Odbojárov 10, 82005 Bratislava, Slovakia

Email: anna.remisova@fm.uniba.sk

\section{References}

APEL, K. O. (1992): Diskurs und Verantwortung. Das Problem des Übergangs zur Postkonventionellen Ethik [Discourse and responsibility. The Problem of the Transition to Postconventional Ethics]. Frankfurt am Main: Surkhamp.

MCDONALD, G. (2015): Business Ethics: A Contemporary Approach. Cambridge: Cambridge University Press.

DIERKSMEIER, C. (2016): What is 'humanistic' about humanistic management? In: Humanist Management Journal, 1(1), pp. 9-32.

GLUCHMAN, V. (2008): Etika a reflexie morálky [Ethics and Reflections of Morality]. Prešov: FF PU.

GLUCHMAN, V. (2017): G. E. Moore and theory of moral/right action in ethics of social consequences. In: Ethics \& Bioethics (in Central Europe), 7(1-2), pp. 57-65.

HABERMAS, J. (1992): Erläuterungen zur Diskursethik [Explanations on Discourse Ethics]. Frankfurt am Main: Surkhamp.

KANT, I. (1999): Kritika praktického rozumu [Critique of Practical Reason]. Bratislava: Spektrum.

KANT, I. (2004): Základy metafyziky mravov [Fundamental Principles of the Metaphysic of Morals]. Bratislava: Kalligram.

LAŠÁKOVÁ, A. \& REMIŠOVÁ, A. (2015): Unethical leadership: Current theoretical trends and conceptualization. In: Procedia Economics and Finance, 34, pp. 319-328.

LAŠÁKOVÁ, A. \& REMIŠOVÁ, A. (2017): On organizational factors that elicit managerial unethical decision-making. In: Ekonomický časopis, 65(4), pp. 334-354.

LAŠÁKOVÁ, A., REMIŠOVÁ, A. \& BÚCIOVÁ, Z. (2015): Teoretická reflexia etického vedenia l'udí [Theoretical Reflection of the Ethical Leadership]. In: Š. Majtán et al.: Aktuálne problémy podnikovej sféry 2015 [Current Problems in Business Sphere 2015]. Bratislava: Ekonóm, pp. 348-357. 
MURÁNSKY, M. (2008): Kantova deontologická etika [Kant's Deontological Ethics]. In: A. Remišová (ed.): Dejiny etického myslenia v Európe a USA [History of Ethical Thinking in Europe and USA]. Bratislava: Kalligram, pp. 330-351.

REMIŠOVÁ, A. (1998): Podnikatel'ská etika ako integračná veda [Business Ethics as an Integrative Science]. In: Filozofia, 53(2), pp. 93-99.

REMIŠOVÁ, A. (1999): Aplikovaná etika [Applied Ethics]. In: Filozofia, 54(4), pp. 228-237. REMIŠOVÁ, A. (2011): Etika a ekonomika [Ethics and Economics]. Bratislava: Kalligram.

REMIŠOVÁ, A. (2015): Súčasné trendy v podnikatel'skej etike [Current Trends in Business Ethics]. Bratislava: Wolters Kluwer.

REMIŠOVÁ, A. \& LAŠÁKOVÁ, A. (2013): K pojmom vedenie l'udí a etické vedenie l'udí [On the Notions of Leadership and Ethical Leadership]. In: Manažment v 21. storoči: problémy a východiská [Management in the $21^{\text {st }}$ Century: Problems and Solutions]. Trenčín: Vysoká škola manažmentu, pp. 283-293.

REMIŠOVÁ, A., LAŠÁKOVÁ, A., RUDY, J., SULÍKOVÁ, R., KIRCHMAYER, Z. \& FRATRIČOVÁ, J. (2016): Ethical Leadership in Slovak Business Environment. Prague: Wolters Kluwer.

TREVINO, L. K., HARTMAN, L. P. \& BROWN, M. (2000): Moral person and moral manager: How executives develop a reputation for ethical leadership. In: California Management Review, 42(4), pp. 128-142.

ULRICH, P. (1993): Transformation der ökonomischen Vernunft. Fortschrittperspektive der modernen Industriegesellschaft [Transformation of Economic Reasons. Progressive Perspective of Modern Industrial Society]. Bern, Stuttgart \& Wien: Haupt.

ULRICH, P. (1995): Führungsethik. Ein grundrechtorientierter Ansatz [Leadership Ethics. A Fundamental Rights-Oriented Approach]. Beiträge und Berichte des Instituts für Wirtschaftsethik an der Hoschschule St. Gallen, Nr. 68.

ULRICH, P. (1997): Integrative Wirtschaftsethik. Grundlagen einer lebensdienlichen Ökonomie [Integrative Business Ethics. Foundations of Life-Serving Economics]. Bern, Stuttgart \& Wien: Haupt. 